\title{
Probiotics in Animal Husbandry: Applicability and Associated Risk Factors
}

\author{
Kazeem Adekunle Alayande $1,2, * \mathbb{C}$, Olayinka Ayobami Aiyegoro ${ }^{3}$ and Collins Njie Ateba ${ }^{1,2}$ \\ 1 Department of Microbiology, North-West University, Mmabatho 2745, South Africa; collins.ateba@nwu.ac.za \\ 2 Food Security and Safety Niche Area, North-West University, Mmabatho 2745, South Africa \\ 3 Agricultural Research Council, Animal Production Institute, Gastrointestinal Microbiology and \\ Biotechnology Division, Irene 0062, South Africa; aiyegoroo@arc.agric.za \\ * Correspondence: jkadekunle2@gmail.com
}

Received: 30 November 2019; Accepted: 7 January 2020; Published: 4 February 2020

check for updates

\begin{abstract}
Probiotics have been emerging as a safe and viable alternative to antibiotics for increasing performance in livestock. Literature was collated via retrieved information from online databases, viz, PubMed, MEDLINE, ScienceDirect, Scopus, Web of Science and Google Scholar. Besides improved immunomodulation and nutrient digestibility, in-feed probiotics have shown drastic reductions in gastrointestinal tract-invading pathogens. However, every novel probiotic strain cannot be assumed to share historical safety with conventional strains. Any strain not belonging to the wild-type distributions of relevant antimicrobials, or found to be harbouring virulence determinants, should not be developed further. Modes of identification and the transmigration potential of the strains across the gastrointestinal barrier must be scrutinized. Other potential risk factors include the possibility of promoting deleterious metabolic effects, excessive immune stimulation and genetic stability of the strains over time. Adverse effects of probiotics could be strain specific, depending on the prevailing immunological and physiological condition of the host. The most crucial concern is the stability of the strain. Probiotics stand a good chance of replacing antibiotics in animal husbandry. The possibility of the probiotics used in animal feed cross-contaminating the human food chain cannot be downplayed. Thus, the established safety measures in probiotic development must be adhered to for a successful global campaign on food safety and security.
\end{abstract}

Keywords: adverse effects; antimicrobial resistance; in-feed probiotics; immunocompromised host; virulence factors

\section{Introduction}

Probiotics have been widely studied because of their ability to modulate gut microbiota and immunological systems in both humans and livestock [1,2], where they serve as prophylaxes and for therapeutic purposes in clinical and veterinary practices [3-5]. Thus, probiotics are considered as an emerging, safe and viable alternative to antibiotics, for increasing the performance of farm animals. The addition of probiotics to animal feed improves growth performance and nutrient digestibility, reduces serum cholesterol and decreases incidence of diarrhoea in dairy animals [6-8]. Probiotics, in addition, have also demonstrated improved aerobic conditions in a gastrointestinal environment through the depletion of oxygen-scavenging compounds such as nitrates. They have shown the ability to secrete hydrolytic enzymes against bacterial toxins and even to inactivate toxin receptors, thus limiting the occurrence of toxin-mediated infections in livestock animals [9].

Undoubtedly, animal feed is crucial in livestock farming and thus has attracted several studies seeking to improve its potency through feed additives. Since the ban of in-feed antibiotics by the European legislation in 2006, the resultant heavy decline in the use of antibiotics paved the way for 
significant reductions in the prevalence of resistance genes among the gut microflora of pigs from Europe [10]. Now that the use of antibiotics as a growth enhancer in livestock diets is being faced with widespread bans across many countries [11], the development of various health functional animal feeds and fermented food products using probiotics as additives has received unprecedented attention across the continents $[12,13]$.

Probiotics are live microorganisms that confer health benefits on the host when administered in adequate dosage. Several species belonging to the genera of Lactobacillus, Streptococcus, Lactococcus and Bifidobacterium remain the most popular probiotic agents to date [14]. These beneficial microbial agents are, at a regulatory level, classified as zootechnical additives [15]. It is required of a probiotic candidate to demonstrate a minimum of one performance feature before being certified for a particular target animal [16]. The desired characteristics of a candidate probiotic may include modulation of immune and certain physiological systems of the host, attenuation of virulent markers on a number of pathogens, treatment and prevention of infectious and inflammatory disease conditions, acting as a biocontrol agent in preventing spoilage, etc. $[2,9,17]$. This review, therefore, serves to highlight the significance of the applications of probiotics in animal husbandry, and the importance of intensive safety analyses of every probiotic candidate before further development into health functional products and their release for public consumption.

\section{Materials and Methods}

Literature was collated via retrieved information from online databases (viz, PubMed, MEDLINE, ScienceDirect, Scopus, Web of Science and Google Scholar) on scientific reports that investigate the application of probiotics and probable risk factors to be considered. We searched the key word "probiotics" and then combined it with "safety", "in-feed antibiotics", "adverse event/effect" and "case report". All searches were carried out between 2017 and 2019. There was no exclusion of any period during the search and no language restrictions applied. The abstracts for all retrieved articles were carefully read to determine eligibility. Articles from 2000 and before were only considered if there was no later study with closely related content. Studies that assessed the intervention of probiotics in animal husbandry and veterinary practice were included. Studies on safety protocols for a typical probiotic candidate and studies on the detrimental impact of in-feed antibiotics on public health were also included, while case reports on the adverse events/effects of probiotic administration on livestock were not found.

\subsection{Significance of Probiotics in Animal Health}

The improvement of growth performance due to probiotics was confirmed through the increased production of volatile fatty acids, nutrient digestibility, feed conversion rate and the stimulation of lactic acid-dependent protozoa [11]. Probiotics have been used to increase the efficiency of the utilisation of feed, to increase milk production and to reduce diarrhoea both in pigs and cattle, and to control the colonisation of the intestinal tract by Salmonella in chickens [16]. Besides its improved immunomodulatory potential, the commercially available in-feed probiotic, Lavipan, drastically reduces the invasion of Campylobacter spp. in the gastrointestinal tract of poultry birds, thus suppressing pathogenic contaminants and improving hygiene in the poultry environment [18].

Roselli et al. [19] observed that probiotics fed to weaned piglets and sows yielded positive results by improving gut health through balanced microbiota, improving immunological and physiological processes, and preventing gastrointestinal disorders. The major responses were observed as prompt changes in the gastrointestinal microbial ecosystem, through antagonizing the survival of the neighbouring pathogens coupled with the production of favourable fermentation products. This was affirmed through a related study by Hanczakowska and colleagues [20], who found that Enterococcus faecium, fed to piglets as feed supplement, exhibited an inhibitory effect against Clostridium perfringens. The microflora within the gastrointestinal environment of animals can be considered an active metabolic organ due to its biodiversity. Therefore, it is important to maintain effective gut microflora in the 
battle against the invasion of pathogens among livestock with high population density [21]. In general, lactic acid bacteria with probiotic potential secrete organic acids which increase the acidity of the gastrointestinal tract environment, and therefore lower the risk of pathogen infestation while at the same time regulating the microbial ecosystem within the gut habitat [22].

A cocktail of probiotic supplements containing strains of Lactobacillus significantly reduces Salmonella and Shigella in the faecal samples of goats [23]. Likewise, a complex mixture of lactobacilli, isolated from the guts of piglets, reportedly increased the density of beneficial microbes and reduced that of enteric pathogens such as Escherichia coli in the gastrointestinal tract [24]. Weaned piglets fed with lactic acid bacteria supplements in their basal diet showed significant improvements in terms of growth performance, digestion rate, faecal microbial count, intestinal morphology, diarrhoea control and maintenance of $\mathrm{pH}$ in the gastrointestinal tract $[25,26]$. Dietary inclusion of lactobacilli has shown increased egg-laying performance in chickens, and improved body weight on a daily basis in turkeys [27].

Specifically, Lactobacillus johnsonii FI9785 was reported to have successfully ameliorated necrotic enteritis due to Clostridium perfringens upon its administration to poultry [28]. Likewise, Lactobacillus salivarius SMXD51 showed effective prevention of gut colonization by Campylobacter jejuni in broiler chickens when administered via oral gavage [29]. Lactobacillus plantarum PCA 236, when used as a feed supplement for goats, repressed their Clostridium gut colonization [30]. Lactobacillus fermentum I5007, when orally administered to four-day-old piglets as a post-weaning supplement, resulted in improved intestinal health, increased the height of jejunum villi, increased the concentrations of butyrate and branched chain fatty acids and reduced potential colon pathogens [31].

Moreover, bifidobacteria constitute an important component in the gut microflora of chickens and have proven records of positive effects when administered to piglets and other mammals. A commercial strain of Bifidobacterium bifidum (InstitutRosell Inc. Montreal, QC, Canada) was effective in the treatment of cellulitis-infected broiler chickens, and B. longum PCB 133 significantly reduced Campylobacter jejuni concentration in poultry faeces when administered to chickens [32,33]. B. adolescentis Z25 equally exhibited significant potential in the treatment of blood sugar imbalance, lipid metabolism disorders, tissue damage and gut microbiota dysbiosis [34]. Several species of Bifidobacterium have also demonstrated great potential to increase production of the enzyme $\beta$-galactosidase, therefore reducing lactose intolerance. B. longum LC67 and L. plantarum LC27 synergistically remedied 2,4,6-trinitrobenzesulfonic acid-induced colitis and liver injury in mice, via readjustment of the gut ecosystem imbalance and inhibition of inflammatory responses [35]. The activities of the probiotics B. adolescentis Z25 and L.plantarum LC27 mentioned above are the output of laboratory research based on mouse models. This might only be relevant to mammalian livestock.

Several probiotic agents have been traditionally applied as bioprotectors on meat products $[3,36]$. They have been reportedly secreting exopolysaccharides that are capable of inhibiting biofilm formation by pathogenic contaminants [37]. Strains of Lactobacillus have also yielded commendable results on raw chicken meat in protection against Listeria monocytogenes and Salmonella enteriditis [38].

In addition, mycotoxins are often found contaminating animal feed, thereby exposing livestock to serious health risks, with a tendency to cross-contaminate the human food chain through meat and other dairy products $[39,40]$. Ochratoxin A, a nephrotoxic, carcinogenic and immunotoxic mycotoxin, was detoxified to a greater extent in chickens after the administration of a lactobacilli-based probiotic preparation [41]. In another study by Chlebicz and Śliżewska [42], monocultures of different strains of Lactobacillus spp. were tested for detoxification potentials against a number of mycotoxins directly used to contaminate animal feed. After $6 \mathrm{~h}$ of incubation, the concentration of fumonisin B1 and B2, aflatoxin B1, T-2 toxin and zearalenone were significantly reduced, by $77 \%, 60 \%, 61 \%$ and $57 \%$, respectively. Several scientific reports have indicated that lactic acid bacteria are capable of detoxifying different forms of mycotoxin. When compared to physical and chemical decontamination methods, biological detoxification is more efficient, specific and environmentally friendly [41,43]. The two main mechanisms by which mycotoxins are detoxified by probiotics involve adsorption of toxins by the 
microbial cell wall and biotransformation. Additionally, combined use of a consortium of probiotics and mycotoxin-degrading enzymes is yet another growing strategy for mycotoxin decontamination $[44,45]$.

\subsection{Probiotics as a Viable Alternative to In-Feed Antibiotics}

Antibiotics have been extensively used over decades as prophylactic and growth-promoting agents in the livestock sector. This has contributed a great deal to the uncontrollable increase in the emergence of multidrug-resistant (MDR) pathogens. This has consequently reduced therapeutic options both in human and veterinary clinics, leading to reduced clinical success on previously curable infections, and in some cases, can result in a prolonged stay in hospital. The MDR pathogens constitute a major setback, hampering progress in public health both in humans and farm animals. Concerted efforts have been made by major stakeholders towards global awareness on the shared consequences of the indiscriminate and irresponsible use of antibiotics. Despite years of relentless campaigning, MDR pathogens continue to emerge.

In-feed antimicrobials are the most common route of drug administration in Europe, especially in pig farming [46]. This form of drug administration predisposes healthy animals to unnecessary antimicrobials while feeding alongside the infected ones, thus increasing the risk of selecting resistant bacteria. Increasing trends in the practices that led to the evolution of antimicrobial resistance genes prompted the United States Animal Agriculture Sector to prohibit the use of subtherapeutic antibiotic growth promoters (AGPs) in early 2017, through implementation of the Veterinary Feed Directive (VFD) $[47,48]$. This highlights an urgent need for more efforts to discover alternative growth promoters.

Moreover, the consumption of antimicrobials by livestock was estimated to be above 240,000 metric tons annually across continents. However, some countries are now experiencing a substantial decline in the sales of antimicrobials for food-producing animals [49]. Resistance associated with the use of antibiotics in agricultural practices, and the potential transfer of MDR pathogens from food-producing animals to humans, is a disturbing health concern [50]. Antibiotics administered to farm animals are often excreted in urine and egested in faeces into the nearby environment, thus potentially selecting the microorganisms in such an environment for the development of multiple resistance genes in a bid for survival [51]. The use of antibiotics in food-producing animals is under intense scrutiny because of the perceived risk of zoonotic transfer of the resistant pathogens into the human populace [52].

For instance, $\beta$-lactam antibiotics such as penicillin, cephalosporin and carbapenem are no longer relevant in human clinical therapy [53]. Despite the high degree of effectiveness of colistin against carbapenemase-producing Enterobacteriaceae, plasmid-mediated mor-1 reportedly emerged in 2015 and, subsequently, was identified in over fifty different countries, along with additional seven $m c r-1$ gene variants [54-56]. Colistin has been in use for several years in the livestock industries in China, and research findings suggest $m c r-1$ originated from animals before spreading to the human population. The agricultural usage of colistin as a growth promoter was consequently banned by the Chinese authorities in 2017 [57].

Furthermore, the emergence of vancomycin-resistant enterococci in European countries was implicated in the illegal use of glycopeptide antibiotics such as avoparcin in animal feeds [58]. In 2016, the Animal Health Authority in France passed a decree regulating the use of critically important antibiotics, such as 3rd- and 4th-generation cephalosporins, fluoroquinolones and macrolides. This was intended to promote the rational use of antibiotics, and to foster the use of alternatives in the veterinary clinical system [59]. Additionally, in the United Kingdom, there was a shared desire to seek an alternative approach to prophylactic measures other than the conventional antimicrobials, and many farmers showed interest in reducing the use of antibiotics. Hence, the guidelines on promoting prudent prescriptions, and providing advice on alternative methods to treat and prevent diseases in pigs, were put together by the Responsible Use of Medicines in Agriculture Alliance (RUMA) in 2013 and the Pig Veterinary Society (PVS) in 2014 [45]. 
In a real-world longitudinal study by Burow and colleagues [60] on the assessment of dynamics of the risk of resistance in Escherichia coli to clinically important antimicrobials in pigs, it was concluded that reduction in antibiotic resistance in pigs could lead to a lower level of beta-lactam-or macrolide-resistant E. coli among their progeny. In another study by Wang et al. [54], Pacific white shrimp feed was supplemented with Ciprofloxacin and Sulfonamide to investigate the microbial community targeting the $\mathrm{V} 4$ region of $16 \mathrm{~S}$ rRNA genes. Four days into the experiment, a significant increase in the abundance of the Ciprofloxacin- and Sulfonamide-resistant genes ( $q n r B, q n r D$, $q n r S$ and sul1, sul2, sul3, respectively) was observed. On a more general note, the clinical preservation and maintenance of treatment options against infectious diseases require the restriction of antibiotic use to unavoidable cases.

Campaigns for the removal of in-feed antibiotics in animal husbandry are increasingly gaining momentum across the globe. This has prompted several studies on developing and promoting alternative additives such as probiotics, prebiotics, plant secondary metabolites, acidifiers, enzymes, bacteriocins and bacteriophages [61,62]. Combined probiotics and exogenous enzymes, when used as feed additives, have demonstrated beneficial impacts on growth performance and on the weight-gains-to-feed ratio in calves [63,64].

The effects of two commercially available feed additives containing lactic acid bacteria, Lactobacillus fermentation products and plant-sourced enzymes, in comparison to in-feed antibiotics, were extensively evaluated based on growth performance, carcass characteristics and blood metabolites of steers by Ran and colleagues [65]. The study established that the supplements improved average daily weight gains and feed efficiency during the early portion of the growing phase. Additionally, steers supplemented with these products required fewer therapeutic antimicrobials compared to the control groups in the experiment, thus confirming probiotic additives as potential alternatives to AGPs in growing steers.

Moreover, a diet of Astyanax bimaculatus supplemented with Lactobacillus spp. resulted in increased amounts of leucocytes in the circulatory system, thus conferring greater resistance to gut pathogens and, consequently, higher survival rates, in addition to improved feed efficiency [66]. In another study conducted by Vase-Khavari et al. [67], poultry bird feed supplemented with probiotics (superzist) revealed significant influences on the growth performance of the broilers, with laudable responses on total cholesterol, triglyceride levels and immunological parameters, and a notable reduction in colon pathogens. Administration of Lactococcus lactis subspecies lactis 2 probiotic to broilers reduced the cholesterol level and fat content in the breast and thigh meat more prominently when compared to the effects of zinc bacitracin antibiotics, which were used as a control [68].

Askelson and colleagues [69] demonstrated the potential of administering a phytate-degrading probiotic culture, in place of feed enzymes, to improve performance in livestock animals. In their study, recombinant Lactobacillus gallinarum and L. gasseri were cloned to express Bacillus subtilis phytase (pTRK882), which improved the weight gain of broiler chickens up to 10-fold and 18-fold, respectively. This could eventually combine the performance benefits of feed enzymes with that of animal health and food safety traditionally associated with probiotics. Moreover, a poultry basal diet supplemented with colonies of Lactobacillus plantarum 16 and Paenibacillus polymyxa 10 led to the maintenance of intestinal barrier integrity and the adequate expression of barrier functional genes, a reduction in the level of malondialdehyde in the jejunal mucosa and serum, an increment in the activities of hepatic glutathione peroxidase, a reduction in the rate of cell proliferation and apoptosis, and a significant reduction in nitric oxide and in the expression of cyclooxygenase-2 enzyme [70].

Direct feeding with a probiotic culture preparation containing Lactobacillus reuteri, L. salivarius and Streptococcus salivarius significantly improved the growth performance, blood parameters and IgG stimulation in weaned piglets [71]. Lactobacillus salivarius LS6 demonstrates promising probiotic traits for potential use as a feed additive for pigs, through preventing disruption of the epithelial cells in the small intestine via inhibiting the colonisation by enterotoxigenic Escherichia coli K88 [72]. Oral administration of Lactobacillus delbrueckii to suckling porcine that were denied access to in-feed antibiotics showed tremendously improved antioxidant capacity and an intestinal immune response 
with long-lasting effects [73]. Tasfaye and Hailu [74] recently compiled several scientific studies to indicate how directly feeding probiotic to dairy cows significantly improves milk production and quality.

\subsection{Established Risk Assessment Protocol for the Probiotics}

Notwithstanding the clinical efficacy of probiotics, the safety of the microorganism involved must be assured. This suggests that the evaluation of the risk factors of a specific strain must receive adequate attention. Most probiotic strains have acquired the "Generally Recognized as Safe" (GRAS) status due to their long history of use as probiotics [74-76]; however, every novel probiotic cannot be assumed to share historical safety with the conventional strains [77]. Just as in other organisms, probiotics may possess undesirable properties such as virulence factors, transferable antimicrobial resistance, haemolytic potential and production of toxic biochemicals [78].

For instance, the potential risk of a horizontal transfer of antimicrobial-resistant genes in a probiotic strain to other bacteria in the microbiota of the host's gastrointestinal environment has been emphasized [76]. This is in addition to rare cases of infectious diseases like endocarditis, bacteraemia, pneumoniae, meningitis and septic arthritis associated with certain Lactobacillus and Enterococcus strains which have also been reported mostly in immuno-compromised patients [79].

During the 2006 two-day workshop organised by academic and industrial scientists on biosafety evaluation of lactic acid bacteria as probiotics, at the University of Antwerp, Belgium, it was recommended that any potential probiotic strain not belonging to the wild-type distributions of relevant antimicrobials, or harbouring a known virulence determinants, should be avoided and not developed as future functional products for human or animal consumption [79]. In a joint report of the Food and Agriculture Organization/World Health Organization (FAO/WHO) Expert Consultation in Rome [80], Enterococcus was mentioned as one of the bacteria with a high potential for virulence features, although from lactic acid bacteria. Participants thus discouraged the use of Enterococcus as a probiotic, on the grounds that the genus commonly expresses a high level of vancomycin-resistant genes. Such resistance can be transferred to neighbouring pathogens, which may, in the end, enhance their pathogenicity. This is coupled with the fact that some strains of vancomycin-resistant enterococci are frequently associated with nosocomial infections.

Moreover, the assessment of the strain identity, coupled with the mode of identification of the strains, deserves adequate attention. The transmigration potential of the strain across the gastrointestinal barrier, which may result in invasive opportunistic infection, should be scrutinized as well [81-83]. Among other potential risk factors to be put under the spotlight are the ability to transfer acquired antimicrobial resistance, the possibility of promoting deleterious metabolic effects, excessive immune stimulation, virulence determinants and toxigenicity of the specific strain, level of purity of the product, and colonisation and genetic stability of the strain over time [79-84].

In addition, the FAO working group report [85] equally recommends that potential probiotic strains should be screened for undesirable secondary medical effects in end users, virulence in animal models with compromised immunity and impending adverse effects on end users. Kim et al. [86] also suggest guidelines for the safety assessment and regulation of probiotics, as endorsed by the European Union Scientific Committee on Animal Nutrition, as follows: taxonomical definition of the strains, collection of substantial information revealing data such ashistory of use, industrial applications, ecological niche, human intervention, exclusion of pathogenicity and description of end users. A chat summarizing combined established safety assessment protocols for a typical probiotic candidate is shown in the Figure 1. 


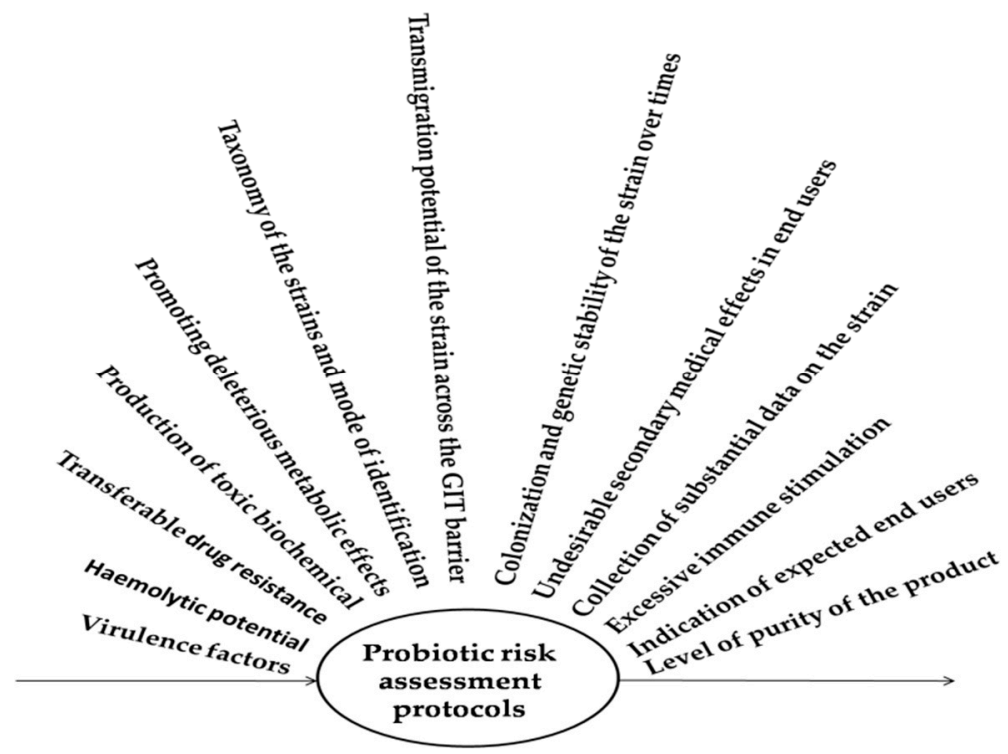

Figure 1. Established safety assessment protocols for a probiotic candidate.

\subsection{Adverse Effects Due to Application of Probiotics}

The safety of probiotics is best discussed in general as it applies to both human and farm animals. The peculiar functions of a probiotic are more important than the source of the isolate. It is crucial that the potential of a probiotic agent remains viable over a considerable period of time at the site of action. It is very difficult to ascertain the source of a microorganism in the gastrointestinal tract since the origin of the intestinal microbiota has not been well founded. Moreover, the possibility of probiotics used in animal feed cross-contaminating the human food chain cannot be downplayed. Although there is very little available information on the risk to human food due to contamination from in-feed probiotics [80,87], the adverse effects of probiotics could be strain specific, depending on the prevailing immunological and physiological condition of the host. In a systematic study on published data and information on the safety of probiotics, credited to the Agency for Healthcare Research and Quality under the US Department of Health and Human Services, it was concluded that there is a lack of assessment and systematic reporting on adverse effects due to probiotic intervention, and that interventions are poorly documented [88].

\section{Conclusions}

Considering the detrimental effects of in-feed antibiotics, and irresponsible administration of antibiotics in veterinary practice, probiotics stand a good chance as a viable alternative prophylactic and therapeutic agent in animal husbandry. Although the events of probiotics turning into opportunistic infections are not well documented, a few available case reports reveal that the likelihood is more pronounced in immunocompromised hosts, and there are few or no reports on affected livestock. The risk of human food contamination from in-feed probiotics is a possibility, although less investigated. Several health agencies and academics across continents have established and documented adequate safety protocols for probiotics development. As tremendous as the benefits of probiotics are, the safety measures for every strain must be strictly adhered to at all levels in order to make the ongoing global campaign on food safety and security a reality.

Author Contributions: O.A.A. conceptualized the study, K.A.A. collected the data and prepared the first draft, C.N.A. and O.A.A. revised and proofread the manuscript. All authors have read and agreed to the published version of the manuscript.

Funding: This research was funded by National Research Foundation and North-West University, South Africa. The APC was funded by North-West University, South Africa. 
Acknowledgments: This work was partly supported by incentive funding for a rated researcher grant from the National Research Foundation, South Africa, awarded to O.A.A., and a research grant from the FNAS Research Committee of North-West University, awarded to C.N.A.

Conflicts of Interest: The authors declare no conflict of interest.

\section{References}

1. Celiberto, L.S.; Bedani, R.; Rossi, E.A.; Cavallini, D.C. Probiotics: The scientific evidence in the context of inflammatory bowel disease. Crit. Rev. Food Sci. Nutr. 2017, 57, 1759-1768. [CrossRef] [PubMed]

2. Chen, J.; Wang, Q.; Liu, C.M.; Gong, J. Issues deserve attention in encapsulating probiotics: Critical review of existing literature. Crit. Rev. Food Sci. Nutr. 2017, 57, 1228-1238. [CrossRef] [PubMed]

3. de Llano, D.G.; Gil-sánchez, I.; Esteban-fernández, A.; Ramos, A.M.; Fernández-díaz, M.; Cueva, C.; Moreno-arribas, M.V.; Bartolomé, B. Reciprocal beneficial effects between wine polyphenols and probiotics: An exploratory study. Eur. Food Res. Technol. 2016, 243, 531-538. [CrossRef]

4. Abushelaibi, A.; Al-mahadin, S.; El-tarabily, K.; Shah, N.P.; Ayyash, M. Characterization of potential probiotic lactic acid bacteria isolated from camel milk. LWT Food Sci. Technol. 2017, 79, 316-325. [CrossRef]

5. Srinivas, B.; Rani, G.S.; Kumar, B.K.; Chandrasekhar, B.; Krishna, K.V.; Devi, T.A.; Bhima, B. Evaluating the probiotic and therapeutic potentials of Saccharomyces cerevisiae strain (OBS2) isolated from fermented nectar of toddy palm. AMB Express 2017, 7, 2. [CrossRef]

6. Cavalheiro, C.P.; Ruiz-Capillas, C.; Herrero, A.M.; Jiménez-Colmenero, F.; Ragagnin, M.C.; Martins, F.L.L. Application of probiotic delivery systems in meat products. Trends Food Sci. Technol. 2015, 46, 120-131. [CrossRef]

7. Zhao, P.; Kim, I. Effect of direct-fed microbial on growth performance, nutrient digestibility, fecal noxious gas emission, fecal microbial flora and diarrhea score in weanling pigs. Anim. Feed Sci. Technol. 2015, 200, 86-92. [CrossRef]

8. Lan, R.; Tran, H.; Kim, I. Effects of probiotic supplementation in different nutrient density diets on growth performance, nutrient digestibility, blood profiles, fecal microflora and noxious gas emission in weaning pig. J. Sci. Food Agric. 2017, 97, 1335-1341. [CrossRef]

9. Hossain, M.I.; Sadekuzzaman, M.; Ha, S.D. Probiotics as potential alternative biocontrol agents in the agriculture and food industries: A review. Food Res. Int. 2017, 100, 63-73. [CrossRef]

10. Xiao, L.; Estellé, J.; Kiilerich, P.; Ramayo-Caldas, Y.; Xia, Z.; Feng, Q.S.; Pedersen, A.Ø.; Kjeldsen, N.J.; Liu, C. A reference gene catalogue of the pig gut microbiome. Nat. Microbiol. 2016, 1, 16161. [CrossRef]

11. Abd El-Tawab, M.M.; Youssef, I.M.; Bakr, H.A.; Fthenakis, G.C.; Giadinis, N.D. Role of probiotics in nutrition and health of small ruminants. Pol. J. Vet. Sci. 2016, 19, 893-906. [CrossRef] [PubMed]

12. Isolauri, E.; Salminen, S.; Ouwehand, A.C. Probiotics. Best Pract. Res. Clin. Gastroenterol. 2004, 18, $299-313$. [CrossRef] [PubMed]

13. Hwang, C.E.; Seo, W.T.; Cho, K.M. Enhanced antioxidant effect of black soybean by cheonggukjang with potential probiotic Bacillus subtilis CSY191. Korean J. Microbiol. 2013, 49, 391-397. [CrossRef]

14. Oliveira, D.; Vidal, L.; Ares, G.; Walter, E.H.M.; Rosenthal, A.; Deliza, R.S. Microbiological and physicochemical screening of probiotic cultures for the development of non-fermented probiotic milk. LWT Food Sci. Technol. 2017, 79, 234-241. [CrossRef]

15. Bernardeau, M.; Vernoux, J. Overview of the use of probiotics in the feed/food chain. Probiotics: Production, evaluation and uses in animal feed. Kerala India Biotechnol. Appl. Biochem. 2009, 2009, 15-45.

16. Bernardeau, M.; Vernoux, J.P. Overview of differences between microbial feed additives and probiotics for food regarding regulation, growth promotion effects and health properties and consequences for extrapolation of farm animal results to humans. Clin. Microbiol. Infect. 2013, 19, 321-330. [CrossRef]

17. Diaz-vergara, L.; Pereyra, C.M.; Montenegro, M.; Pena, G.A.; Aminahuel, C.A.; Cavaglieri, L.R. Encapsulated whey-native yeast Kluyveromyces marxianus as a feed additive for animal production. Food Addit. Contam. Part A 2017, 34, 750-759. [CrossRef]

18. Smialek, M.; Burchardt, S.; Koncicki, A. The influence of probiotic supplementation in broiler chickens on population and carcass contamination with Campylobacter spp-Field study. Res. Vet. Sci. 2018, 118, 312-316. [CrossRef] 
19. Roselli, M.; Pieper, R.; Rogel-Gaillard, C.; De Vries, H.; Bailey, M.; Smidt, H.; Lauridsen, C. Immunomodulating effects of probiotics for microbiota modulation, gut health and disease resistance in pigs. Anim. Feed Sci. Technol. 2017, 233, 104-119. [CrossRef]

20. Hanczakowska, E.; Świątkiewicz, M.; Natonek-Wiśniewska, M.; Okoń, K. Medium chain fatty acids (MCFA) and/or probiotic Enterococcus faecium as a feed supplement for piglets. Livest. Sci. 2016, 192, 1-7. [CrossRef]

21. Gaggia, F.; Mattarelli, P.; Biavati, B. Probiotics and prebiotics in animal feeding for safe food production. Int. J. Food Microbiol. 2010, 141, S15-S28. [CrossRef] [PubMed]

22. Servin, A.L. Antagonistic activities of lactobacilli and bifidobacteria against microbial pathogens. FEMS Microbiol. Rev. 2004, 28, 405-440. [CrossRef] [PubMed]

23. Apás, A.L.; Dupraz, J.; Ross, R.; González, S.N.; Arena, M.E. Probiotic administration effect on fecal mutagenicity and microflora in the goat's gut. J. Biosci. Bioeng. 2010, 110, 537-540. [CrossRef] [PubMed]

24. Chiang, M.L.; Chen, H.C.; Chen, K.N.; Lin, Y.C.; Lin, Y.T.; Chen, M.-J. Optimizing production of two potential probiotic lactobacilli strains isolated from piglet feces as feed additives for weaned piglets. Asian Australas. J. Anim. Sci. 2015, 28, 1163. [CrossRef] [PubMed]

25. Giang, H.H.; Viet, T.Q.; Ogle, B.; Lindberg, J.E. Growth performance, digestibility, gut environment and health status in weaned piglets fed a diet supplemented with potentially probiotic complexes of lactic acid bacteria. Livest. Sci. 2010, 129, 95-103. [CrossRef]

26. Dowarah, R.; Verma, A.K.; Agarwal, N.; Patel, B.H.M.; Singh, P. Effect of swine based probiotic on performance, diarrhoea scores, intestinal microbiota and gut health of grower-finisher crossbred pigs. Livest Sci. 2017, 195, 74-79. [CrossRef]

27. Gadde, U.; Kim, W.H.; Oh, S.T.; Lillehoj, H.S. Alternatives to antibiotics for maximizing growth performance and feed efficiency in poultry: A review. Anim. Health Res. Rev. 2017, 18, 26-45. [CrossRef]

28. La Ragione, R.; Narbad, A.; Gasson, M.; Woodward, M.J. In vivo characterization of Lactobacillus johnsonii FI9785 for use as a defined competitive exclusion agent against bacterial pathogens in poultry. Lett. Appl. Microbiol. 2004, 38, 197-205. [CrossRef]

29. Saint-Cyr, M.J.; Haddad, N.; Taminiau, B.; Poezevara, T.; Quesne, S.; Amelot, M.; Daube, G.; Chemaly, M.; Dousset, X.; Guyard-Nicodeme, M. Use of the potential probiotic strain Lactobacillus salivarius SMXD51 to control Campylobacter jejuni in broilers. Int. J. Food Microbiol. 2017, 247, 9-17. [CrossRef]

30. Maragkoudakis, P.A.; Mountzouris, K.C.; Psyrras, D.; Cremonese, S.; Fischer, J.; Dalaka, E.; Hadjipetrou, A.; Theofanous, G.; Strozzi, G.P.; Carlini, N. Functional properties of novel protective lactic acid bacteria and application in raw chicken meat against Listeria monocytogenes and Salmonella enteritidis. Int. J. Food Microbiol. 2009, 130, 219-226. [CrossRef]

31. Liu, H.; Zhang, J.; Zhang, S.; Yang, F.; Thacker, P.A.; Zhang, G.; Qiao, S.; Ma, X. Oral administration of Lactobacillus fermentum I5007 favors intestinal development and alters the intestinal microbiota in formula-fed piglets. J. Agric. Food Chem. 2014, 62, 860-866. [CrossRef] [PubMed]

32. Santini, C.; Baffoni, L.; Gaggia, F.; Granata, M.; Gasbarri, R.; Di Gioia, D.; Biavati, B. Characterization of probiotic strains: An application as feed additives in poultry against Campylobacter jejuni. Int. J. Food Microbiol. 2010, 141, S98-S108. [CrossRef] [PubMed]

33. Estrada, A.; Wilkins, D.C.; Drew, M. Administration of Bifidobacterium bifidum to chicken broilers reduces the number of carcass condemnations for cellulitis at the abattoir. J. Appl. Poult. Res. 2001, 10, 329-334. [CrossRef]

34. Zhu, G.; Ma, F.; Wang, G.; Wang, Y.; Zhao, J.; Zhang, H.; Chen, W. Bifidobacteria attenuate the development of metabolic disorders, with inter-and intra-species differences. Food Funct. 2018, 9, 3509-3522. [CrossRef] [PubMed]

35. Jang, S.E.; Jeong, J.J.; Kim, J.K.; Han, M.J.; Kim, D.H. Simultaneous Amelioratation of Colitis and Liver Injury in Mice by Bifidobacterium longum LC67 and Lactobacillus plantarum LC27. Sci. Rep. 2018, 8, 7500. [CrossRef] [PubMed]

36. Chaillou, S.; Christieans, S.; Rivollier, M.; Lucquin, I.; Champomier-Verges, M.-C.; Zagorec, M. Quantification and efficiency of Lactobacillus sakei strain mixtures used as protective cultures in ground beef. Meat Sci. 2014, 97, 332-338. [CrossRef] [PubMed]

37. Kim, Y.; Kim, S.H. Released exopolysaccharide (r-EPS) produced from probiotic bacteria reduce biofilm formation of enterohemorrhagic Escherichia coli O157: H7. Biochem. Biophys. Res. Commun. 2009, 379, 324-329. [CrossRef] 
38. Maragkoudakis, P.A.; Mountzouris, K.C.; Rosu, C.; Zoumpopoulou, G.; Papadimitriou, K.; Dalaka, E.; Hadjipetrou, A.; Theofanous, G.; Strozzi, G.P.; Carlini, N. Feed supplementation of Lactobacillus plantarum PCA 236 modulates gut microbiota and milk fatty acid composition in dairy goats-A preliminary study. Int. J. Food Microbiol. 2010, 141, S109-S116. [CrossRef]

39. Gajecka, M.; Jakimiuk, E.; Skorska-Wyszynska, E.; Zielonka, Ł.; Polak, M.; Paluszewski, A.; Rybarczyk, L.; Gajecki, M. Influence of zearalenone micotoxicosis on selected immunological, haematological and biochemical index of blood plasma in bitches. Pol. J. Vet. Sci. 2004, 7, 175-180.

40. Anfossi, L.; Giovannoli, C.; Baggiani, C. Mycotoxin detection. Curr. Opin. Biotechnol. 2016, 37, $120-126$. [CrossRef]

41. Markowiak, P.; Ślizewska, K.; Nowak, A.; Chlebicz, A.; Zbikowski, A.; Pawłowski, K.; Szeleszczuk, P. Probiotic microorganisms detoxify ochratoxin A in both a chicken liver cell line and chickens. J. Sci. Food Agric. 2019, 99, 4309-4318. [CrossRef]

42. Chlebicz, A.; Śliżewska, K. In Vitro Detoxification of Aflatoxin B1, Deoxynivalenol, Fumonisins, T-2 Toxin and Zearalenone by Probiotic Bacteria from Genus Lactobacillus and Saccharomyces cerevisiae Yeast. Probiotics Antimicrob. Proteins 2019. [CrossRef] [PubMed]

43. Zhu, Y.; Hassan, Y.I.; Lepp, D.; Shao, S.; Zhou, T. Strategies and methodologies for developing microbial detoxification systems to mitigate mycotoxins. Toxins 2017, 9, 130. [CrossRef]

44. Milani, J.; Heidari, S. Stability of ochratoxin A during bread making process. J. Food Saf. 2017, 37, 1-6. [CrossRef]

45. Wang, N.; Wu, W.; Pan, J.; Long, M. Detoxification Strategies for Zearalenone Using Microorganisms: A Review. Microorganisms 2019, 7, 208. [CrossRef]

46. Sarrazin, S.; Joosten, P.; Gompel, L.V.; Luiken, R.E.C.; Mevius, D.J.; Wagenaar, J.A.; Heederik, D.J.J. Quantitative and qualitative analysis of antimicrobial usage patterns in 180 selected farrow-to-finish pig farms from nine European countries based on single batch and purchase data. J. Antimicrob. Chemother. 2019, 74, 807-816. [CrossRef]

47. Helm, E.T.; Curry, S.; Trachsel, J.M.; Schroyen, M.; Gabler, N.K. Evaluating nursery pig responses to in-feed sub-therapeutic antibiotics. PLOS ONE 2019, 14, e0216070. [CrossRef]

48. Johnson, T.A.; Sylte, M.J.; Looft, T. In-feed bacitracin methylene disalicylate modulates the turkey microbiota and metabolome in a dose-dependent manner. Sci. Rep. 2019, 9, 8212. [CrossRef]

49. Vieco-Saiz, N.; Belguesmia, Y.; Raspoet, R.; Auclair, E.; Gancel, F.; Kempf, I.; Drider, D. Benefits and Inputs from Lactic Acid Bacteria and Their Bacteriocins as Alternatives to Antibiotic Growth Promoters During Food-Animal Production. Front. Microbiol. 2019, 10, 57. [CrossRef]

50. Cattaneo, A.A.; Wilson, R.; Doohan, D.; Lejeune, J.T. Bovine veterinarians' knowledge, beliefs, and practices regarding antibiotic resistance on Ohio dairy farms. J. Dairy Sci. 2009, 92, 3494-3502. [CrossRef]

51. Qiao, M.; Ying, G.-G.; Singer, A.C.; Zhu, Y.-G. Review of antibiotic resistance in China and its environment. Environ. Int. 2018, 110, 160-172. [CrossRef]

52. Coyne, L.A.; Latham, S.M.; Dawson, S.; Donald, I.J.; Pearson, R.B.; Smith, R.F.; Williams, N.J.; Pinchbeck, G.L. Antimicrobial use practices, attitudes and responsibilities in UK farm animal veterinary surgeons. Prev. Vet. Med. 2018, 161, 115-126. [CrossRef] [PubMed]

53. Temkin, E.; Adler, A.; Lerner, A.; Carmel, Y. Carbapenem-resistant Enterobacteriaceae: Biology, epidemiology, and management. Ann. N. Y. Acad. Sci. 2014, 1323, 22-42. [CrossRef] [PubMed]

54. Wang, Q.; Huang, S.Q.; Li, C.Q.; Xu, Q.; Zeng, Q.P. Akkermansiamuciniphila May Determine Chondroitin Sulfate Ameliorating or Aggravating Osteoarthritis. Front. Microbiol. 2017, 8, 1955. [CrossRef] [PubMed]

55. Sun, J.; Zhang, H.; Liu, Y.-H.; Feng, Y. Towards Understanding MCR-like Colistin Resistance. Trends Microbiol. 2018, 26, 794-808. [CrossRef] [PubMed]

56. Wang, X.; Wang, Y.; Zhou, Y.; Li, J.; Yin, W.; Wang, S.; Zhang, S.; Shen, J.; Shen, Z.; Wang, Y. Emergence of a novel mobile colistin resistance gene, mcr-8, in NDM-producing Klebsiella pneumoniae. Emerg. Microbes Infect. 2018, 7, 1-9. [CrossRef]

57. Xia, X.; Wang, Z.; Fu, Y.; Du, X.-D.; Gao, B.; Zhou, Y.; He, J.; Wang, Y.; Shen, J.; Jiang, H.; et al. Association of colistin residues and manure treatment with the abundance of mcr-1 gene in swine feedlots. Environ. Int. 2019, 127, 361-370. [CrossRef] 
58. Song, X.; Huang, Q.; Zhang, Y.; Zhang, M.; Xie, J.; He, L. Rapid multiresidue analysis of authorized/banned cyclopolypeptide antibiotics in feed by liquid chromatography-tandem mass spectrometry based on dispersive solid-phase extraction. J. Pharm. Biomed. 2019, 170, 234-242. [CrossRef]

59. Bourély, C.; Fortanéd, N.; Calavas, D.; Leblond, A.; Gay, É. Why do veterinarians ask for antimicrobial susceptibility testing? A qualitative study exploring determinants and evaluating the impact of antibiotic reduction policy. Prev. Vet. Med. 2018, 159, 123-134. [CrossRef]

60. Burow, E.; Rostalski, A.; Harlizius, J.; Gangl, A.; Simoneit, C.; Grobbel, M.; Kollas, C.; Tenhagen, B.-A.; Käsbohrer, A. Antibiotic resistance in Escherichia coli from pigs from birth to slaughter and its association with antibiotic treatment. Prev. Vet. Med. 2019, 165, 52-62. [CrossRef]

61. Seal, B.S.; Drider, D.; Oakley, B.B.; Brüssow, H.; Bikard, D.; Rich, J.O.; Miller, S.; Devillard, E.; Kwan, J.; Bertin, G.; et al. Microbial-derived products as potential new antimicrobials. Vet. Res. 2018, 49, 66. [CrossRef]

62. Cowieson, A.J.; Kluenter, A.M. Contribution of exogenous enzymes to potentiate the removal of antibiotic growth promoters in poultry production. Anim. Feed Sci. Technol. 2019, 250, 81-92. [CrossRef]

63. Ponce, C.H.; Dilorenzo, N.; Quinn, M.J.; Smith, D.R.; May, M.L.; Galyean, M.L. Case study: Effects of a directfed microbial on finishing beef cattle performance, carcass characteristics, and in vitro fermentation. Prof. Anim. Sci. 2011, 27, 276-281. [CrossRef]

64. Kocyigit, R.; Aydin, R.; Yanar, M.; Diler, A.; Avci, M.; Ozyurek, S. The Effect of Direct-Fed Microbials Plus Exogenous Feed Enzyme Supplements on the Growth, Feed Efficiency Ratio and Some Behavioural Traits of Brown Swiss x Eastern Anatolian Red F1 Calves. Pak. J. Zool. 2016, 48, 1389-1393.

65. Ran, T.; Gomaa, W.M.S.; Shen, Y.Z.; Saleem, A.M.; Yang, W.Z.; McAllister, T.A. Use of naturally sourced feed additives (lactobacillus fermentation products and enzymes) in growing and finishing steers: Effects on performance, carcass characteristics and blood metabolites. Anim. Feed Sci. Technol. 2019, 254, 114190. [CrossRef]

66. De Moraes, A.V.; Pereira, M.D.O.; Moraes, K.N.; Rodrigues-Soares, J.P.; Jesus, G.F. Autochthonous probiotic as growth promoter and immunomodulator for Astyanax bimaculatus cultured in water recirculation system. Aquac. Res. 2018, 49, 2808-2814. [CrossRef]

67. Vase-Khavari, K.; Mortezavi, S.-H.; Rasouli, B.; Khusro, A.; Salem, A.Z.M. The effect of three tropical medicinal plants and superzist probiotic on growth performance, carcass characteristics, blood constitutes, immune response, and gut microflora of broiler. Trop. Anim. Health Prod. 2019, 51, 33-42. [CrossRef] [PubMed]

68. Mujnisa, A.; Gustina, L.; Natsir, A.; Hasan, S. Dosage Effects of Lactococcuslactis ssp. lactis 2 as a Probiotic on the Percentage of Carcass, Abdominal Fat Content and Cholesterol Level in Broilers. Int. J. Poult. Sci. 2018, 17, 100-105. [CrossRef]

69. Askelson, T.E.; Campasino, A.; Lee, J.T.; Duong, T. Evaluation of Phytate-Degrading Lactobacillus Culture Administration to Broiler Chickens. Appl. Environ. Microbiol. 2013, 80, 943-950. [CrossRef]

70. Wu, Y.; Wang, B.; Zeng, Z.; Liu, R.; Tang, L.; Gong, L.; LI, W. Effects of probiotics Lactobacillus plantarum 16 and Paenibacilluspolymyxa 10 on intestinal barrier function, antioxidative capacity, apoptosis, immune response, and biochemical parameters in broilers. Poult. Sci. 2019, 98, 5028-5039. [CrossRef]

71. Dlamini, Z.C.; Langa, R.L.S.; Aiyegoro, O.A.; Okoh, A.I. Effects of probiotics on growth performance, blood parameters, and antibody stimulation in piglets. S. Afr. J. Anim. Sci. 2017, 47. [CrossRef]

72. Yeo, S.; Lee, S.; Park, H.; Shin, H.; Holzapfel, W. Development of putative probiotics as feed additives: Validation in a porcine-specific gastrointestinal tract model. Appl. Microbiol. Biotechnol. 2016, 100, 10043-10054. [CrossRef]

73. Li, Y.; Hou, S.; Peng, W.; Lin, Q.; Chen, F.; Yang, L.; Li, F.; Huang, X. Oral Administration of Lactobacillus delbrueckii during the Suckling Phase Improves Antioxidant Activities and Immune Responses after the Weaning Event in a Piglet Model. Oxidative Med. Cell. Longev. 2019, 6919803. [CrossRef]

74. Tesfaye, A.; Hailu, Y. The Effects of Probiotics Supplementation on Milk Yield and Composition of Lactating Dairy Cows. J. Phytopharmacol. 2019, 8, 12-17. [CrossRef]

75. Tsai, C.C.; Leu, S.F.; Huang, Q.R.; Chou, L.C.; Huang, C.C. Safety evaluation of multiple strains of Lactobacillus plantarum and Pediococcuspentosaceus in Wistar rats based on the Ames test and a 28-day feeding study. Sci. World J. 2014, 928652. [CrossRef] 
76. Plessas, S.; Nouska, C.; Karapetsas, A.; Kazakos, S.; Alexopoulos, A.; Mantzourani, I.; Chondrou, P.; Fournomiti, M.; Galanis, A.; Bezirtzoglou, E. Isolation, characterization and evaluation of the probiotic potential of a novel Lactobacillus strain isolated from Feta-type cheese. Food Chem. 2017, 226, 102-108. [CrossRef]

77. Donohue, D.C. Safety of probiotics. Asia Pac. J. Clin. Nutr. 2006, 15, 563-569.

78. Lee, S.; Lee, J.; Jin, Y.-I.; Jeong, J.-C.; Chang, Y.H.; Lee, Y.; Jeong, Y.; Kim, M. Probiotic characteristics of Bacillus strains isolated from Korean traditional soy sauce. LWT Food Sci. Technol. 2017, 79, 518-524. [CrossRef]

79. Vankerckhoven, V.; Huys, G.; Vancanneyt, M.; Vael, C.; Klare, I.; Romond, M.; Entenza, J.M.; Moreillon, P.; Wind, R.D.; Knol, J.; et al. Biosafety assessment of probiotics used for human consumption: Recommendations from the EU-PROSAFE project. Trends Food Sci. Technol. 2008, 19, 102-114. [CrossRef]

80. Report of a Joint FAO/WHO Expert Consultation on Evaluation of Health and Nutritional Properties of Probiotics in Food including Powder Milk with Live. In Health and Nutrition Properties of Probiotics in Food including Powder Milk with Live Lactic Acid Bacteria; FAO Food and Nutrition Paper 85; FAO: Rome, Italy, 2006.

81. Sanders, M.E.; Akkermans, L.M.; Haller, D.; Hammerman, C.; Heimbach, J.; Hormannsperger, G.; Huys, G.; Levy, D.D.; Lutgendorff, F.; Mack, D.; et al. Safety assessment of probiotics for human use. Gut Microbes 2010, 1, 164-185. [CrossRef]

82. Huys, G.; Botteldoorn, N.; Delvigne, F.; De Vuyst, L.; Heyndrickx, M.; Pot, B.; Dubois, J.J.; Daube, G. Microbial Characterization of Probiotics-Advisory Report of theWorking Group "8651 Probiotics" of the Belgian Superior Health Council (SHC). Mol. Nutr. Food Res. 2013, 57, 1479-1504. [CrossRef] [PubMed]

83. Suresh, K.; Srinath, K.; Pravesh, B. Safety concerns of Probiotic use: A review. IOSR J. Dent. Med. Sci. 2013, 12, 56-60.

84. Sornplang, P.; Piyadeatsoontorn, S. Probiotic isolates from unconventional sources: A review. J. Anim. Sci. Technol. 2016, 58, 26. [CrossRef] [PubMed]

85. Joint FAO/WHO Working Group Report on Drafting Guidelines for the Evaluation of Probiotics in Food; Food and Agriculture Organization of the United Nations: Rome, Italy, 30 April and 1 May 2002. Available online: https://www.who.int/foodsafety/fs_management/en/probiotic_guidelines.pdf (accessed on 6 April 2019).

86. Kim, M.J.; Ku, S.; Kim, S.Y.; Lee, H.H.; Jin, H.; Kang, S.; Li, R.; Johnston, T.V.; Park, M.S.; Ji, G.E. Safety Evaluations of Bifidobacterium bifidum BGN4 and Bifidobacterium longum BORI. Int. J. Mol. Sci. 2018, 19, 1422. [CrossRef] [PubMed]

87. Bajagai, Y.S.; Klieve, A.V.; Dart, P.J.; Bryden, W.L. Probiotics in Animal Nutrition-Production, Impact and Regulationby FAO Animal Production and Health Paper No. 179; Harinder, P.S., Ed.; FAO: Rome, Italy, 2016; ISBN 978-92-5-109333-7.

88. Hempel, S.; Newberry, S.; Ruelaz, A.; Wang, Z.; Miles, J. Safety of Probiotics to Reduce Risk and Prevent or Treat Disease. Evidence Report/Technology Assessment No. 200; (Prepared by the Southern California Evidence-Based Practice Center under Contract No. 290-2007-10062-I.) AHRQ Publication No. 11-E007; Agency for Healthcare Research and Quality: Rockville, MD, USA, 2011.

(C) 2020 by the authors. Licensee MDPI, Basel, Switzerland. This article is an open access article distributed under the terms and conditions of the Creative Commons Attribution (CC BY) license (http://creativecommons.org/licenses/by/4.0/). 